\title{
FOREST FIRE RISKS IN FOREST VALUATIONS ${ }^{1}$ BY GEORGE C. WILKES ${ }^{2}$
}

Graduated in forestry from University of Toronto in 1949. Joined staff of Forest Economics Section, Federal Forestry Branch in same year. Received M.Sc.F. degree in forest economics from Toronto in 1952. Previous publications include a survey of Canada's forest economy, an analysis of taxation of the forest industries in Ontario, and a review of forest taxation in Europe and the United States.

\section{$A B S T R A C T$}

The influence of the risk of fire loss is important in forest valuations. Risks of loss which cannot be covered by insurance are usually provided for in the interest rate used in calculations of the forest's value.

The simplest estimate of the risk of loss from forest fire is the actual average annual burning rate for the Forest area. If this specific information does not exist for the area to be evaluated or is not readily available, this method of appraisal of risk is of little use.

The author suggests how to estimate roughly the forest fire risks for different types of forests in different parts of Canada on the basis of the published work on forest fire protection standards by Mr. H.W. Beall, Federal Forestry Branch. The report shows how the estimate of risk may be incorporated in the interest rate used in the evaluation of the forest.

The influence of the risk of fire loss on forest valuations comprises the central theme of this paper. This analysis attempts to clarify some of the problems which arise when, in making an estimate of the value of a forest property, one must make adequate provision for the possibility of future losses from forest fires.

In valuations, risks of loss that cannot be covered by insurance are usually provided for in the interest rate used in the calculations because interest includes the reward paid to invested capital for the risks to which the capital is exposed. So long as forest fire risks are uninsurable, it is reasonable to expect that the interest rate on forest investments should be large enough to include a reward for the possibility of forest fire losses. This premise is followed in this analysis and the author suggests how to estimate the interest rate so as to allow for risks of forest fire loss. This interest rate can then be used in estimating either present or future values of timber stands.

\footnotetext{
"The author gratefully acknowledges the helpful criticisms and suggestions in preparing this paper, given by Prof. T. W. Dwight, Prof. D. V. Love and Prof. D. C. MacGregor, University of Toronto; Prof. Scott Gordon, Carleton College; Mr. H. B. Shepard, Federal Reserve Bank of Boston; and by Dr. Allon Peebles, Mr. H. W. Beall and other members of the Federal Forestry Branch.

${ }^{2}$ Department of Northern Affairs and National Resources, Forestry Branch, Ottawa. Submitted for publication February 22, 1955.
} 


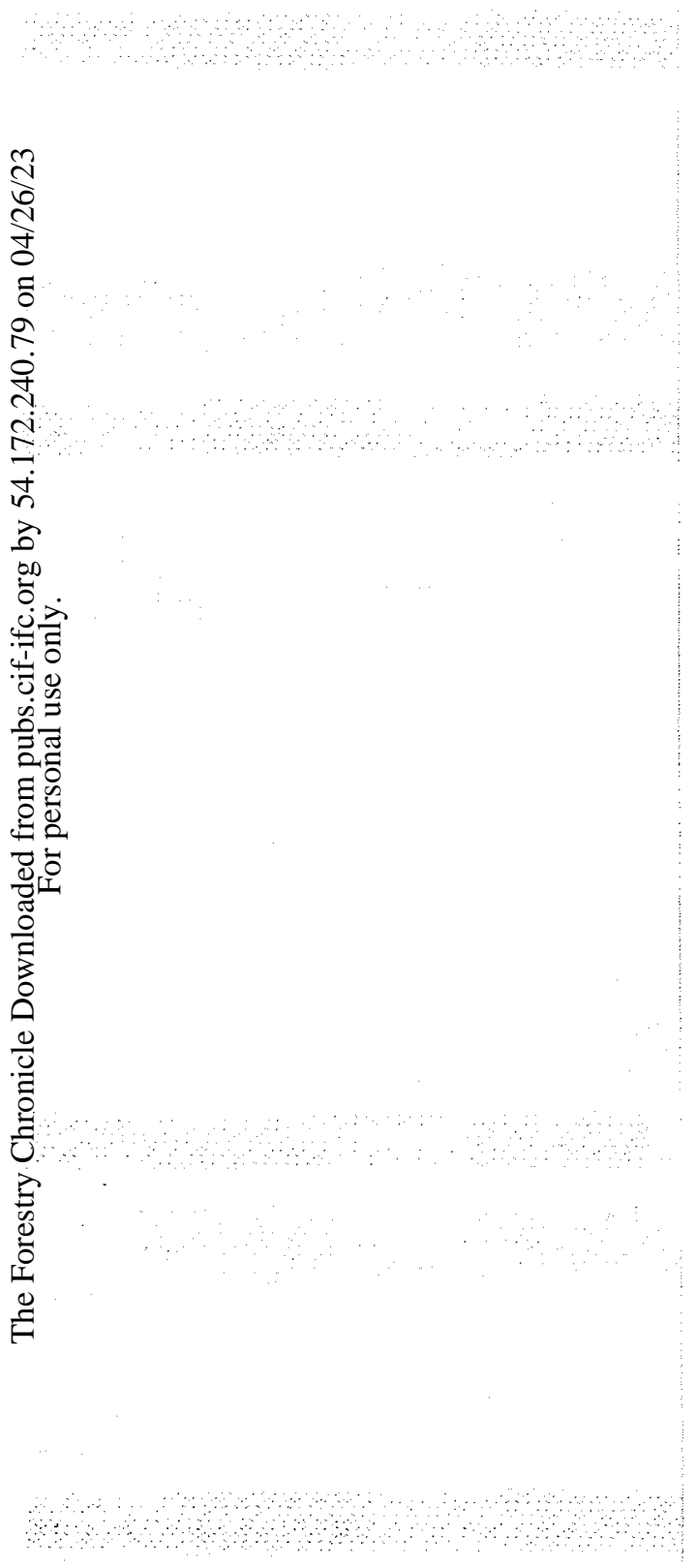

PART I

FOREST FIRE RISK

If appropriate data on forest values and on the extent and value of forest fire losses were available, forest fire risks could be computed readily. Yet, although much effort has been spent in Canada collecting and analyzing forest fire statistics, it is precisely these value data which are not available in a suitable form for risk calculations. Lacking adequate information on such forest values, we must be content to estimate risk largely on the basis of the areas burned by forest fires.

For any forest or forest region, the simplest estimate of the risk of loss trom forest fire is the actual average annual burning rate for the area. This burning rate is the long-period average ${ }^{(3)}$ of the forest area burned each year, and it can be used as a measure of the forest fire risk if we make the conservative assumption that when a forest fire occurs, 100 per cent of the timber burned is destroyed. Furthermore we must also assume that the forest's value is distributed evenly over the whole area so that if, say, one per cent of the area is burned each year, one per cent of the value is destroyed.

The procedure for estimating forest fire risks, which has just been described, is of little use if the specific information does not exist for the area being evaluated or is not readily available to those wishing to make the forest valuation. Under such circumstances, a distinct advantage lies in developing a method to estimate roughly the forest fire risk for different types of forest in different parts of Canada where the estimates can be based on published information. In the following paragraphs the writer develops such a method based on the work of forest fire protection standards by H. W. Beall of the Federal Forestry Branch.

Beall's recent study (') suggests a series of "acceptable" average percentages of forest areas burned annually which may be used as fire control objectives or standards by forest protection services. This series covers different forest types within the different forest fire protection zones across Canada. For example, Beall suggests 0.1 per cent as an acceptable average annual burned area percentage for spruce forests in zone eleven which comprises most of. Ontario, Quebec and New Brunswick. There is a different percentage for each forest type in the thirteen zones which are classified. These "acceptable" percentages are annual burning rates which are compatible with the practice of sound forest management in the different zones, and which attempt to incorporate the principles of the least-loss theory of fire control whereby the optimum protection level is where combined damage and cost are at a minimum ${ }^{(5)}$. The zones themselves are broad regions where reasonably uniform fire control policies could be applied to specific forest types. The forest protection service in an area is considered up to the standard suggested by Beall if its long-term average burning rate does not exceed these acceptable per-

${ }^{3}$ The period covered by the records should be at least greater than 10 years for large regions and longer still for snaller areas. The records should also cover a period when intensity of protection has been uniform.

- Beall, H. W., 1949. An outline of forest fire protection standards. For. Chron. 25 (2) pp. 82-106. See particularly Table 5, p. 93.

- See explanation by Beall, idem. pp. 8j-84. 
centages ${ }^{(0)}$. It should be emphasized that Beall's figures are objectives whose limits should not be exceeded on the average over at least a ten-year period.

Now the problem is to relate Beall's published burned area percentage standards to the risk of forest fire loss in the same forest types in each of the forest fire protection zones. As mentioned above, if we assume in the absence of suitable volume and value loss data, that 100 per cent timber loss occurs on a burned area and, moreover, that a forest's value is evenly distributed across the total forest area, we can make a conservative appraisal of the proportion of a forest's value lost by fire. This is almost certain to exceed the actual risk which we at present do not know.

The burned area objectives developed by Beall are burning rates likely to be achieved when forest fire protection services in the different protection zones reach acceptable standards of performance. Therefore, we can consider loss rates derived from his data and based on the above assumptions as to the volume and value of timber destroyed, as the minimum risks of incurring forest fire loss which will prevail when protection services are up to these standards. If protection services in an area not up to this standard ${ }^{(7)}$, risk figures would have to be increased above the minimum suggested above, possibly in some inverse proportion to the quality of the service.

This proposal for minimum risk calculations can be demonstrated as follows by using spruce stands in zone eleven as before. With an acceptable average burned area of 0.1 per cent, the minimum rate to represent the risk of fire which could be expected in such spruce stands would be 0.1 per cent of the forest's value. This risk rate of 0.1 per cent would be covered in the interest rate so as to allow for risk of fire loss in valuations of such spruce stands.

The minimum fire risk rates which can be developed from the other acceptable burning rates drawn up by Beall should be computed relative to the risk rate for spruce. This is because Beall calculated his acceptable burning rates for other forest types in the different forest zones in relation to the base rate he established for spruce in zone eleven. As an example of these other minimum fire risk rate calculations, let us take poplar stands in zone eleven. The area percentage of these poplar stands which could be expected, on the average, to be burned annually is $2 \frac{1}{2}$ times the proportion for spruce stands; that is, the acceptable average annual burning rate is 0.25 per cent. Because poplar generally has a lower value and because the stands re-establish themselves more readily than spruce, a larger area can be permitted to burn before equivalent losses are incurred. Therefore, to find the loss rate for poplar relative to spruce it is necessary to multiply the loss rate for spruce by the ratio of the burning rates for spruce and poplar. E.g., $0.1 \times 0.1=0.04$ per cent. Expressed

$$
\overline{0.25}
$$

- These standard percentages have taken account of numerous risk-evaluation factors and were based on the best information available in 1948. Beall's formula for computing his series allows for differing conditions of productivity of forest land, destructibility of the forest, ease of reestablishment, fuel-hazard, lightning risk, accessibility, climate, topography, and other factors.

${ }^{7}$ In the development of this study, Beall has emphasized that the standards he proposed are conservative objectives and should be considered as but approximations to the optimum standards Beall pointed out further that in many forest regions protection services have a long way to go to achieve his proposed standards. 
as a formula we get the equation:

$$
\frac{\text { burned area per cent, spruce }}{\text { burned area per cent, poplar }}=\frac{\text { risk rate, poplar }}{\text { risk rate, spruce }}
$$

The minimum risk rate for poplar is lower than the rate for spruce because the risks of fire loss and the values at risk in poplar stands are lower than in spruce.

Table 1 of minimum average annual risk rates covering losses from forest fires has been drawn up by following the procedure outlined above. It corresponds to the table of acceptable average annual burned area percentages prepared by Beall.

TABLE 1

Minimum Average Annual Risk Rates Covering Losses FROM FOREST FIRE

Per CENT ${ }^{1}$

\begin{tabular}{|c|c|c|c|c|c|c|c|c|c|c|c|c|c|}
\hline Forest Type & & & & & & Zone & & & & & & & \\
\hline & 1 & 2 & 3 & 4 & 5 & 6 & 7 & 8 & 9 & 10 & 11 & 12 & 13 \\
\hline Experimental Forest & & & & & & & & & & & & & \\
\hline Areas & .50 & .50 & .50 & .50 & .50 & .... & .50 & .50 & .50 & -... & .50 & .50 & \\
\hline Recreational Forest & & & & & & & & & & & & & \\
\hline Areas & .25 & .20 & .17 & .17 & .17 & $\ldots$ & .20 & .14 & .14 & $\ldots$ & .20 & .14 & \\
\hline $\begin{array}{l}\text { Productive Forest } \\
\text { Areas }\end{array}$ & & & & & & & & & & & & & \\
\hline Softwood Types: & & & & & & & & & & & & & \\
\hline Eastern White Pine & $-\ldots$ & 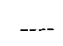 & ---- & $\ldots$ & ---- & $\cdots$ & --- & ---- & - & $\ldots$ & .10 & .11 & \\
\hline Red Pine & $\ldots$ & --- & --- & --- & - & - & $\ldots$ & - & $-\ldots$ & $\ldots$ & .08 & .08 & \\
\hline Jack and Lodgepole & & & & & & & & & & & & & \\
\hline Pines & --- & --- & .03 & .03 & .03 & .01 & .03 & .04 & .03 & .01 & .04 & .04 & .01 \\
\hline Ponderosa Pine & --- & $\ldots$ & .04 & $\ldots$ & $\ldots$ & ---- & --.- & -... & -- & - & -- & $-\cdots$ & \\
\hline Tamarack & $\ldots$ & - & $\cdots$ & $\ldots$ & $\ldots$ & --- & --- & --- & .07 & .03 & .08 & .10 & .03 \\
\hline Spruces & .17 & .10 & .07 & .07 & .07 & .04 & .08 & .10 & .07 & .03 & .10 & .11 & .04 \\
\hline Hemlocks & .13 & .08 & - & .07 & .07 & 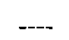 & $\ldots$ & $\ldots$ & $\ldots$ & $\ldots$ & .08 & .10 & $\ldots$ \\
\hline Douglas Fir & .10 & .08 & .04 & .05 & .05 & $-\ldots$ & .05 & $\ldots$ & $\ldots$ & $\ldots$ & - & נ-ב- & $\ldots$ \\
\hline Balsam Firs & .13 & .08 & .07 & .07 & .07 & .03 & .07 & .08 & .07 & .02 & .08 & .10 & .03 \\
\hline Cedars & .14 & .10 & .07 & .07 & .07 & --- & $-\cdots$ & - & - & --- & .08 & .10 & $\ldots$ \\
\hline Eastern W. (-R) Pine- & & & & & & & & & & & & & \\
\hline $\begin{array}{l}\text { Spruce }(-\mathrm{Hem}) \\
\text { J. or L. Pine-Spruce }\end{array}$ & $\cdots$ & -- & --- & $\cdots$ & --- & $-\cdots$ & --- & ---- & --- & -- & .10 & .11 & \\
\hline (-B. Fir) & ---- & --- & .05 & .05 & .05 & .03 & .05 & .07 & .05 & .02 & .07 & .07 & .03 \\
\hline $\begin{array}{l}\text { L. or P. Pine-D. Fir } \\
\text { (-W. Larch) }\end{array}$ & -..- & $\ldots$ & .04 & .04 & .04 & $\ldots$ & - ב. & ---- & -.. & ---- & ---- & - & \\
\hline Spruce-B. Fir & --- & -- & .07 & .07 & .07 & .03 & .08 & .10 & .07 & .03 & .10 & .11 & .03 \\
\hline Spruce-Hem. (-D. or & & & & & & & & & & & & & \\
\hline B. Fir) (-Cedar) & .14 & .10 & ---- & .07 & .07 & $\ldots$ & --- & $\ldots$ & $-\cdots$ & $-\cdots$ & $\ldots$ & $\cdots$ & $\cdots$ \\
\hline $\begin{array}{l}\text { Black Spruce-Tam. } \\
\text { (-Cedar) }\end{array}$ & & & -..- &.- & $\ldots$ & .03 & - & .07 & .05 & .03 & .08 & .08 & .03 \\
\hline
\end{tabular}

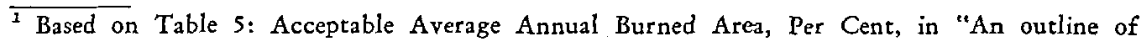
forest fire protection standards" by H. W. Beall, 1949. Forestry Chronicle, 25(2). p. 93. 
TABLE 1 (Cont'd)

Minimum Average Annual Risk Rates Covering Losses

FROM FOREST FIRE

PER CENT ${ }^{2}$

\begin{tabular}{llllllllllllll}
\hline Forest Type & 1 & 2 & 3 & 4 & 5 & 6 & 7 & 8 & 9 & 10 & 11 & 12 & 13
\end{tabular}

D. Fir.-W. Larch

D. Fir-Cedar-Hem.

(-West. W. Pine) Cedar-Hem.

(-West. W. Pine)

Hardwood Types

Black Cottonwood

Poplars

White Birches

Tolerant Hdwds.

Mixedwood Types

Eastern W(-R) Pine-

Poplar (-W. Birch)

J. or L. Pine (-D. Fir)-

Poplar (-W. Birch)

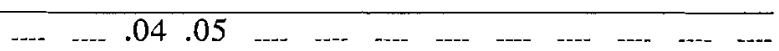

$$
.13 .08
$$

.14 .10 .07 .07

$$
\begin{array}{lllllllllllll}
.07 & .05 & .04 & .04 & .04 & .02 & & & 04 & & & & \\
0 & & 03 & 03 & .03 & .01 & .03 & .03 & .02 & .01 & .04 & .04 & .01
\end{array}
$$

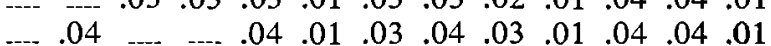$$
\begin{array}{llllllllll}
.08 & .07 & & & & & & & & \\
0
\end{array}
$$

Spruce and/or B. Fir-

Poplar and/or W. Bir.

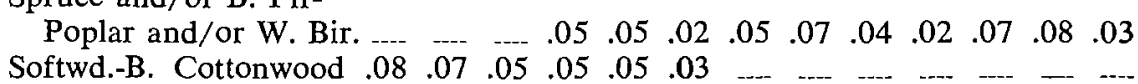

Softwd.-Tol. Hdwd.

Non-Productive Forest

Areas

Non-Forested Areas

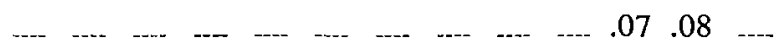

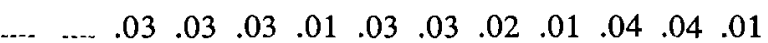

${ }^{8}$ Less than .005 per cent.

\section{Risk of Loss From Other Natural Agents}

Although the risk of forest fire loss in forest valuations is the main consideration in this note, some discussion, albeit a cursory one, must be accorded those risks associated with windstorms, insect infestations, disease epidemics, and other natural destructive agents. Often the forest loss sustained from such agents far exceeds that of fire. Furthermore, only limited action to avoid serious loss may be possible in many instances. For this reason considerable risks are incurred on account of these natural agents.

It is unfortunate that the statistical data covering the losses inflicted by these agents are meagre and inadequate at present. Yet if the size of such losses compared to the size of forest fire losses were known, a rough estimate of the risk could possibly be made. This would be on the basis of the risks calculated for forest fires. A risk rate for these other natural risks could be computed proportional to the fire risk rate on the basis of the ratio of losses. For example, if it is estimated that the losses from these other natural agents in the eastern white pine forests in zone eleven equal the losses from fire, then the risk rate would be 0.10 per cent, the same as the fire risk rate. This rate could be added to that 
for fire giving a composite risk rate for losses from all natural agents of 0.20 per cent for these pine forests.

\section{PART II}

Part I of this paper has dealt with the calculation of the risk of forest fire loss and losses from other natural agents. It is pertinent now to discuss how the risk rates that can be computed for these losses will be used in forest valuations. This discussion covers briefly the economic significance of risk and then analyses the component elements of interest rates and their relationship to risk. Attention is also given to the use of insurance to cover risks in appraisals of value. An appendix to this paper provides detailed illustrations of the use of interest rates in certain types of forest valuations.

\section{ECONOMIC Significance of Risk}

A forest's economic value lies in the financial return it will yield to the operator on his investment. The estimate of the amount of return a forest may be expected to yield depends upon the various elements comprising this return. The rate of return will also depend upon how it is computed-upon what the rate is based, whether gross or net values are used, etc. An investor in a forest enterprise may expect one rate of return; a forest manager, another; a tax assessor may use still another.

Risk in economic affairs derives from the existence of uncertainty in the minds of businessmen as to the success of their business endeavors. The term "risk" is usually limited to uncertainty which can be measured or estimated; that is, expressed in the form of a probability ration or rate ${ }^{8}$. Any uncertainty which is not susceptible to measurement or estimation and whose economic influence cannot be appraised, is not considered in this paper.

Risk is important economically because, in an undertaking whose outcome is uncertain, investors expect a return on their capital commensurate with the degree of risk involved-the greater the risk, the higher the return expected, and vice versa. Removal or reduction of risk, moreover, will contribute to a reduction of the reward for risk expected by the investor and hence also to a reduction in the costs of the enterprise.

\section{Risk and the COMPONENT Elements of INTEREST Rates}

Where capital is placed in a hazardous investment, the net return or "interest" on the investment may be divided into two parts, one of which is called "pure" or "risk-free" interest and the other the "reward for risk taking". Although seemingly different in origin, these two forms of income have several things in common: both arise from putting capital to use; both accrue to the owner of the capital; and the amount of each is determined to a greater or lesser degree on competitive principles.

In this discussion, interest rates are looked upon as being composed of three elements: risk-free interest; the reward for business risk; and the reward for non-business risk. The last two are but a further classification of the "reward for risk taking" according to the types of risk considered.

${ }^{8}$ Knight, F. H. Risk, Uncertainty, and Profit. p. 19. 


\section{(a) Risk-Free Interest}

Pure or risk-free interest may be said to equal the return to capital in the least hazardous investments of which the best example is the long-term government bond. The interest is paid more because the investor, by making his investment, has postponed spending his capital on consumers' goods than because there is any risk involved in the investment.

\section{(b) Reward for Business Risk}

Where capital is exposed to commercial or other economic events which may adversely affect the business enterprise, the investor expects an additional reward over and above the risk-free rate, to be paid on account of the risk involved. Such business risks include the possibility of financial loss when prices fluctuate (possibly owing to changes in current supply and demand or to more basic economic factors), or when consumers' tastes change. For analytical purposes it is advantageous to classify as "external" those business risks which impinge on a firm from the outside. These risks which derive from occurrences within a business firm, such as some labor strikes, can be termed "internal" business risks.

\section{(c) Reward for Non-business Risk}

This reward arises because of risk from events and conditions which are more or less independent of business forces; for example, natural disasters or other vagaries of nature or the unevenness of mineralized zones in ore bodies. These natural or "non-business" risks where the investment is in forest property, include the risk of loss from forest fire whether or not of natural origin. Therefore, an investor may well expect this additional reward (rate of interest) to be paid on his capital if it is exposed to risks of this sort.

\section{(a) Business Risk Rates}

Determination of Appropriate Risk Rates of InTERest

Because business risks are difficult to measure or estimate, it is also difficult to forecast an appropriate interest rate for them. We may, of course, expect that a businessman can forecast internal business risks better than external ones and can take action to minimize or eliminate them more readily: interest rates for internal risks should, therefore, be considerably lower than those for external risks. External business risk appears to vary directly, though not necessarily proportionately, with the length of period under forecast: the more distant the date for realizing a value, the greater the uncertainty that it will be realized, and therefore the greater should be the reward for bearing it ".

In forest valuation, when we are trying to decide what interest rate will cover business risks, it seems reasonable that we should consider what interest an investor in a forest enterprise is likely to demand as a satisfactory return on his investment as well as what interest rate will be offered to attract capital into the industry. If such are the guiding principles, the rate of interest used ${ }^{0}$ In Canada, these government bonds at present are yielding around 3.5 per cent annually. This rate is used in Tables 2 and 3.

${ }^{20}$ This discussion of interest rates and the rewards for risk-taking is necessarily brief and does not allow for discussion of other important factors and their influence on risk such as the uniformity of the risk over time, the individual's liquidity preference, or relative levels of income of different investors. See Ciriacy-Wantrup, S. V. in Resource Conservation, Chapter 11, and Davis, K. P. in American Forest Management, Chapter 15, for discussions of these points. 
seems likely to approximate the returns currently being paid by successful forest enterprises.

This rate of interest, as used in valuations, may well be greater than the long-term average rate of return earned on their investments by all the businesses in the industry. The long-term average return tends to be low because both successful and unsuccessful businesses are taken into account. The use of the long-term average rate in forest valuations seems under the circumstances to be unrealistic to the author.

If, in a given situation, it is considered that the interest rate to be used is 6 per cent, then after deducting 3.5 per cent from this rate to account for risk-free interest, it will be shown that most of the remaining 2.5 per cent would be paid for business risk.

\section{(b) Non-Business Risk Rates}

As pointed out above, the reward for non-business risks, where the investment includes a forested property, covers risks of loss from forest fires. The reward also covers losses from other natural agents such as windstorms, insects and disease. The determination of the risk rate which will cover such risks was discussed in Part $I$ of this paper and a method was suggested whereby an estimate of the appropriate rates can be obtained. Table 1 gives suggested minimum average annual forest fire risk rates. For productive forest areas, these rates range from 0.17 per cent to below 0.01 per cent.

\section{Risks From Forest Fires Compared With Business Risks}

On analysing the components of interest rates, we find that although we may use a single figure to represent our measure of uncertainty, it is a compound of many parts. This also indicates the multiplicity of factors influencing the level and structure of interest rates. When we try to ascertain what interest rate to use under a given set of circumstances, it is helpful first of all to give quantitative values to the component elements of risk in order to determine the composite figure. This procedure assists in ensuring that the factors involved receive adequate consideration.

An appraisal of value may use methods wherein interest rates are used to compound values or to discount them. Tables 2 and 3 illustrate how our preceding analysis may be used to determine what interest rate would be used in the valuation of a forest property. The figures in the "Calculated Interest Rates" columns give the single composite values from which to select the appropriate rate. The figures have been chosen for illustrative purposes only; yet every effort has been taken to make them as realistic as possible.

We are now in a position to make some comparison of the relative importance of non-business risks and business risks. Within the limitations of our assumptions in this analysis, non-business risks would seem likely to be small by comparison with other risks which beset the forest operator. This is probably because losses from natural causes appear to be more easily predictable than losses arising out of human action. If the former may be predicted with greater certainty, and if they are more susceptible to control, there is less uncertainty and less risk involved. Consequently risk rates are lower. This situation is likely to obtain even though fire protection services are considerably below the standards suggested by $\mathrm{H}$. W. Beall. 
TABLE 2

INTEREST RATES FOR ESTIMATING TIMBER VALUES

(ZONE EleVEN)

In Percentages

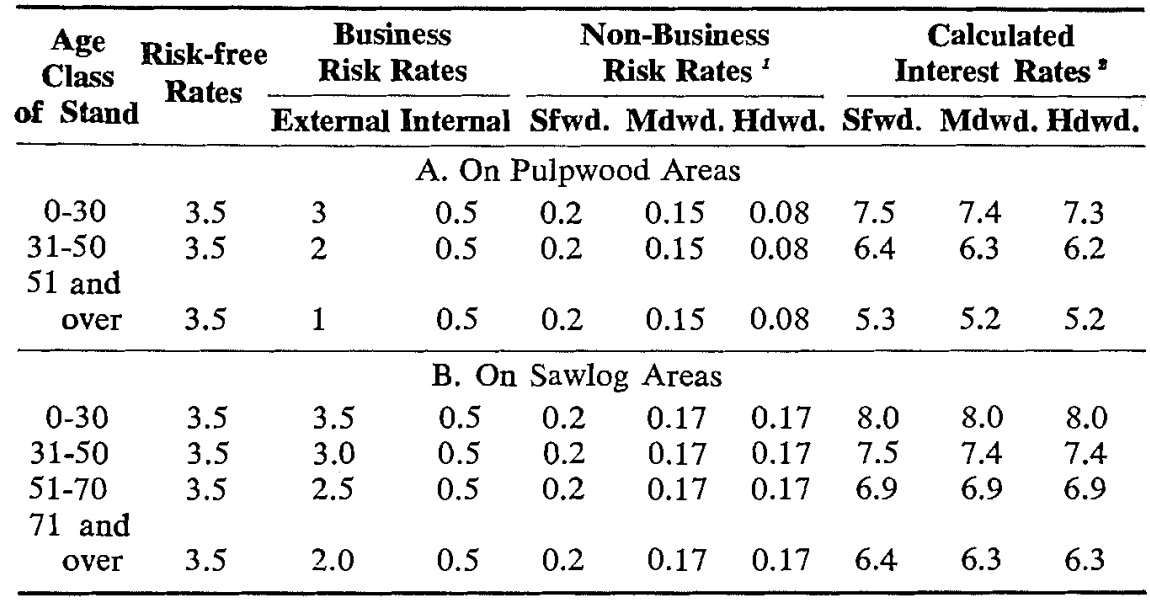

${ }^{1}$ Non-business risk rates cover losses from fire and other agents and have been computed by taking the appropriate minimum rates in the Table 1, assuming standard protection services and doubling them as an allowance for risks from agents other than fire. This assumes that losses from these other agents approximately equal the losses from fire. Stands used to represent softwood, mixedwued and hardwood cover types in zone eleven are:

Softwood type:

Mixedwood type:

Pulpwood areas: spruce

Sawlog areas: Eastern white or red pine-spruce or hemlock

Pulpwood areas: spruce and/or balsam fir-poplar and/or white birch

Sawlog areas: softwood-tolerant hardwoods

Hardwood type:

Pulpwood areas: poplar or white birch

Sawlog areas: tolerant hardwoods

Figures rounded to first decimal point.

The procedure for determining the interest rate necessary to cover a given risk rate may be expressed by the following formula; (see Davis, K. P. in American Forest Management, p. 300):

$$
\mathrm{E}=\frac{\mathrm{P}+\mathrm{R}}{100} \times 100
$$

where $\mathrm{E}=$ effective rate consisting of risk-free rate plus risk rate

$\mathrm{P}=$ risk-free rate of interest

$\mathrm{R}=$ risk rate expressed as a per cent of expected annual loss of total capital invested

To illustrate for the total rate for softwood stands in the $0-30$ age class in the above table:

$$
\begin{aligned}
E & =\frac{3.5+(3.0+0.5+0.2)}{100-(3.0+0.5+0.2)} \times 100 \\
& =\frac{7.2 \times 100}{96.3} \\
& =7.5 \text { per cent }
\end{aligned}
$$


TABLE 3

INTEREST RATES For Estimating VALUES OF Forest LAND Producing a Sustained Annual Yield of Timber (ZONE ELEVEN) IN Percentages

\begin{tabular}{|c|c|c|c|c|c|c|}
\hline \multirow[t]{2}{*}{$\begin{array}{l}\text { Cover } \\
\text { Type }\end{array}$} & \multirow[t]{2}{*}{$\begin{array}{c}\text { Risk-free } \\
\text { Rate }\end{array}$} & \multirow[t]{2}{*}{$\begin{array}{c}\text { Business } \\
\text { External }\end{array}$} & \multirow[t]{2}{*}{$\frac{\text { Risk Rates }}{\text { Internal }}$} & \multicolumn{2}{|c|}{$\begin{array}{c}\text { Non-Business Risk } \\
\text { Rates for } \\
\text { Reduced Productivity }\end{array}$} & \multirow[t]{2}{*}{$\begin{array}{l}\text { Calculated } \\
\text { Interest } \\
\text { Rates }\end{array}$} \\
\hline & & & & Land & Yield & \\
\hline \multicolumn{7}{|c|}{ A. In Pulpwood Areas } \\
\hline Softwood & 3.5 & 2.5 & 0.5 & 0.05 & 0.2 & 7.0 \\
\hline Mixedwood & 3.5 & 2.5 & 0.5 & 0.05 & 0.15 & 6.9 \\
\hline Hardwood & 3.5 & 2.5 & 0.5 & 0.05 & 0.08 & 6.8 \\
\hline \multicolumn{7}{|c|}{ B. In Sawlog Areas } \\
\hline Softwood & 3.5 & 2.5 & 0.5 & 0.05 & 0.2 & 7.0 \\
\hline Mixedwood & 3.5 & 2.5 & 0.5 & 0.05 & 0.17 & 6.9 \\
\hline Hardwood & 3.5 & 2.5 & 0.5 & 0.05 & 0.17 & 6.9 \\
\hline
\end{tabular}

1 This item is analogous to the non-business risk of timber loss in Table 2 and provides for the possible reduction in the fertility of the land and thus for a drop in productivity-the "land" portion-as well as for a reduction in the total yield of income over time due to destruction of timber-the 'yield' portion. The risk of reduced yield has been computed in a manner similar to the non-business risk in Table 2.

2 The external business risk rates are lower in Table 3 than the long-term external rates in Table 2 because forest property is considered to be a more flexible business property if it is under management for a sustained annual yield.

sigures rounded to first decimal point. See footnote $\left(^{2}\right)$ to Table 2 for formula used to determine rates.

\section{RISK AND INSURANCE}

The relationship of insurance to risks of loss is a significant one. Accordingly some discussion of this relationship is necessary in order to complete this analysis of risks of fire loss in forest valuations.

Because insurance ${ }^{11}$ would seem to provide a simple, straight-forward method of allowing for risk when the probable loss can be ascertained with reasonable accuracy from actuarial data, the question may arise,-if it is preferable, why not buy insurance and forget rewards for risk bearing? The answer could well be that although sufficient data may be available by which insurance rates could be calculated, the size of the premium may actually make it a less economiical proposition than the payment of the expected risk rate of interest on capital. Furthermore, the provision of insurance may depend on the insurer obtaining a minimum number of insurance purchasers - a number which may exceed those interested in taking out policies. Finally although insurance may provide a given degree of security, it may not be possible to provide insurance coverage for 100 per cent of the value involved. This situation-quite com-

\footnotetext{
7 Insurance can be defined as the social device whereby a large number of risks may be consolidated so that what may constitute financial uncertainty for an individual is spread, or averaged, over a large number of people, and converted into a cost of loss for the group. If the number of independent risks is sufficiently large and if accurate statistical data are available, the element of uncertainty can be replaced almost entirely by mathematical certainty.
} 
mon where forests are to be insured-means there is a residual amount of risk for which insurance coverage cannot be obtained. Therefore, where insurance is either not available to provide total or partial security in a business enterprise, or is uneconomic, a reward for risk-taking must be paid for capital. This can be accomplished by means of an interest premium for risk bearing.

\section{Conclusions}

Estimates of the magnitude of forest fire risks have tended in the past to show a wide variation much of which can be attributed to inadequate knowledge of the factors involved. Although we still have a long way to go in Canada before we can claim that our fire loss statistics are adequate for all valuation purposes, yet the existing data are such that much can be accomplished in estimating risks of fire loss.

In this paper, we have discussed the theory and economic importance of risk and have pointed out that the interest rate used for forest valuations may be viewed as being compounded of three elements: a risk-free interest rate; a reward for business risks; and a reward for non-business risks. In the absence of appropriate volume and value data for forest losses, area data may be used to estimate risks of loss if certain assumptions are made as to the distribution of the timber on the area, and as to the volume destroyed when burned. Where specific fire loss records are lacking for an area which is to be evaluated, this study of the problem suggests that the "acceptable annual average burned area percentages", computed by $H$. W. Beall as protection standards, may be used to estimate the levels of fire risk in different forest types across Canada. These would be general risk figures applicable in the different regions. Nevertheless, we emphasize that the use of specific data pertinent to a given forest region is preferable if the available records can be considered reliable. ${ }^{12}$

The method of estimating the levels of forest fire risk developed in this article has been illustrated by choosing risk rates computed on the assumption that forest fire protection services achieve the protection standards suggested by Beall. The subsequent analysis based on this assumption indicates that losses from forest fires and other natural agents would have relatively minor economic significance in forest valuations. This conclusion does not mean, however, that actual losses to a particular forest operator will be negligible: neither does it mean that the total loss in a given region can be disregarded in the formulation of economic or forest policies, nor that we need not expand our efforts in forest protection. An operator can achieve a low loss record for his forests only if they are given adequate protection. Similarly, adequate protection is essential to reducing the general economic burden of these forest losses. Furthermore, protection services must be kept constantly up to standard if a low loss record is to be maintained over many years.

Where insurance is available to cover risks of loss, it is more preferable to use insurance than to allow for risk by including it in the interest rate See footnote 3. 
used in valuation proceedings. By means of insurance, risk is converted to an explicit cost of operations to be met by the business enterprise. If we include risk in the interest rate as a reward for risk taking, the risk payment is only an implicit cost, one which cannot appear as a contractual cost in the accounts of the business.

This analysis of the risk of forest fire losses in forest valuations has brought out the importance of having adequate statistics on fire losses. Furthermore, the discussion serves to emphasize the need for fuller, yet more precise, data on the losses sustained by forest operators from windstorms, disease and insect attacks, and business risks. With better knowledge of these significant economic factors available, sounder and more accurate forest valuations can be achieved.

\section{APPENDIX}

This Appendix provides, in detail, sample calculations of forest valuations designed to illustrate the discounting of non-business risks in forest valuations. In the first example, the forest is being managed for a sustained annual yield of timber, and in the second, it is being purchased for future clear cutting and subsequent sale of the property. The formulae used to make these valuations are as follows:

1. Present value of a forest managed for a sustained annual yield of timber:

$\mathrm{Vo}=\frac{\mathrm{r}}{\mathrm{p}}$

where Vo $=$ present worth,

$r=$ net annual income from the forest

$\mathrm{p}=$ interest rate used to discount future income as per Table 3.

2. Present value of a forest being purchased for clear cutting at a future date and subsequent disposal of the property, soil accorded a nominal value.

Vo $\frac{=R}{(1+p)^{n}}-\frac{e\left(1+p^{n}-1\right)}{p(1+p)^{n}}+s$

where Vo $=$ present worth

$R=$ net value of the timber at maturity

$\mathrm{e}=$ amount of annual expense for administration and taxes

$\mathrm{n}=$ period to cutting date

$\mathrm{p}=$ interest rate used to discount future value as per Table 2. $\mathrm{s}=$ nominal value of land.

\section{Illustration of Valuation Procedures}

(a) To illustrate the first formula-for a forest managed to produce a sustained annual yield of timber-let us assume we are valuing a mixed wood forest in central New Brunswick (zone eleven) which is producing sawlogs, with a net mean annual increment of $30 \mathrm{cu}$. ft. per acre per year, all species, on the basis of 100 per cent stocking. That is, the growth rate averages the same for both softwood and hardwood species. The distribution of species is 40 per cent softwoods and 60 per cent hardwoods and, therefore, the net mean annual increment figure is composed of $12 \mathrm{cu}$. ft. of softwood and $18 \mathrm{cu}$. ft. of hardwood. 
Actual stocking we may assume to be 80 per cent. Current stumpage prices are $\$ 25.00$ per M. f.b.m. (or $200 \mathrm{cu}$. ft.) for softwoods and $\$ 15.00$ per M. f.b.m. for hardwoods. These stumpage prices are net, that is, they exclude all costs save annual land taxes and administration charges which amount to $25 \mathrm{c}$ per acre each year.

\section{Valuation}

Value of net mean annual increment, per acre

$$
\begin{aligned}
& \text { Softwood }=\frac{12.0}{200} \times .8 \times \$ 25.00=\$ 1.20 \text { per acre. } \\
& \text { Hardwood }=\frac{18.0}{200} \times .8 \times \$ 15.00=\$ 1.08 \text { per acre. }
\end{aligned}
$$

Total, all species $=\$ 2.28$ per acre.

Deduct admin. expenses

Net total and taxes $=\$ .25$ per acre.

Present capital value of forest land:

$$
\frac{\$ 2.03}{.069}=\$ 29.42 \text { per acre. }
$$

(b) To illustrate the second formula-for a stand of timber to be clearcut at a future date, with subsequent disposal of the property which is given only a nominal value-let us assume we are valuing a softwood stand in central New Brunswick. The principal product cut will be sawlogs when the stand is some 80 years old. The stand is at present in the 31- to 50-year age class with stocking estimated to be 80 per cent at maturity. The distribution of species in the forest is 95 per cent softwood species and 5 per cent hardwoods. The net mean annual increment is $30 \mathrm{cu}$. ft. per acre per year, all species, on the basis of 100 per cent stocking: this means that $28.5 \mathrm{cu}$. $\mathrm{ft}$. per acre per year is softwood and $1.5 \mathrm{cu}$. ft. is hardwood. Stumpage values are $\$ 25.00$ per M. f.b.m. (or 200 cu. ft.) for softwoods and $\$ 15.00$ per M. f.b.m. for hardwoods. These stumpage values are net, that is, they exclude all costs except land taxes and administration charges which amount to $25 \mathrm{c}$ per acre each year. The discount period to be used for discounting timber in the 31 - to 50-year age class is 40 years; this is the average period of the age class to rotation age. The bare land is given a nominal value of $\$ 2.50$ per acre.

\section{Valuation}

Volume of timber when cut at maturity, per acre:

Formula: Net mean annual increment $\mathrm{X}$ rotation period $\mathrm{X}$ stocking per cent.

Softwood species $=28.5 \times 80 \times .8=1824 \mathrm{cu}$. $\mathrm{ft}$.

Hardwood species $=1.5 \times 80 \times .8=96 \mathrm{cu}$. $\mathrm{ft}$.

Value of timber at maturity at current stumpage values: Softwoods $=1824 \times \$ 25.00=\$ 228.00$ per acre.

$$
\overrightarrow{200}
$$


Hardwoods $=\frac{96}{200} \times \$ 15.00=\$ 7.20$ per acre.

Total, all species $=\$ 235.20$ per acre.

Total value of annual administration charges and land taxes at maturity date:

$$
\begin{aligned}
& \$ .25 \times\left(1.075^{40}-1\right) \\
& .075 \\
& =\frac{\$ .25 \times 17.04}{.075} \\
& =\$ 56.80 \text { per acre. }
\end{aligned}
$$

Present worth of timber and land

$$
\begin{aligned}
& =\frac{\$ 235.20}{(1.075)^{40}}-\frac{\$ 56.80}{(1.075)^{40}}+\$ 2.50 \\
& =\frac{\$ 235.20}{18.04}-\frac{\$ 56.80}{18.04}+\$ 2.50 \\
& =\$ 9.89+\$ 2.50=\$ 12.39 \text { per acre. }
\end{aligned}
$$

\section{REFERENCES}

BEALL, H. W., 1949. An outline of forest fire protection standards. For. Chron. 25:82-106. CHAPMAN, H. H. and W. H. MEYER, 1947. Forest valuation. McGraw-Hill Book Co. Inc., New York. xiit521 pp.

CHATURVEDI, M. D., 1929. The rate of interest in forestry. Indian Forester LV:10-20 and 74-80.

CIRIACY-WANTRUP, S. V., 1952. Resource conservation. U. of California Press, Berkeley. 395 pp.

DAVIS, K. P., 1954. American forest management. McGraw-Hill Book Co. Inc., New York. xiii+482 pp.

GUTTENBERG, S., 1950. The rate of interest in forest management. Jour. For. 48:3-7.

KNIGHT, F. H., 1933. Risk, uncertainty, and profit. London School of Economics and Political Science. Reprints of Scarce Tracts in Economic and Political Science, No. 16. Houghton Mifflin Co. Cambridge. 381 pp.

PETRINI, S., 1953. Elements of forest economics. Oliver and Boyd. Edinburgh. viii +210 pp. PINGREE, D., 1933. Rate of return in forest investment. Jour. For. 31:584-587.

ROTHERY, J. E., 1941. Some interest factors. Jour. For. 39:680-684.

SHEPARD, H. B., 1939. Forest fire insurance in the Northeastern States. U.S.D.A. Tech. Bull. 651. Washington, D.C.

SHEPARD, H B., 1937. Forest fire insurance in the Pacific Const States. U.S.D.A. Tech. Bull. 551. Washington, D.C.

SHEPARD, W., 1925. The bogey of compound interest. Jour. For. 23:251-259.

THOM, R. and M. ANDERSON, 1953. Illinois fire damage appraisal system. U.S.F.S. Fire Control Notes 14:32-34.

WILLET, A. H., 1951. The economic theory of risk and insurance. U. of Penna. Press, Philadelphia (Reprint of The Columbia U. Press 14:(2). Studies in History, Economics and Public Law, 1901), xxviü+103 pp. 